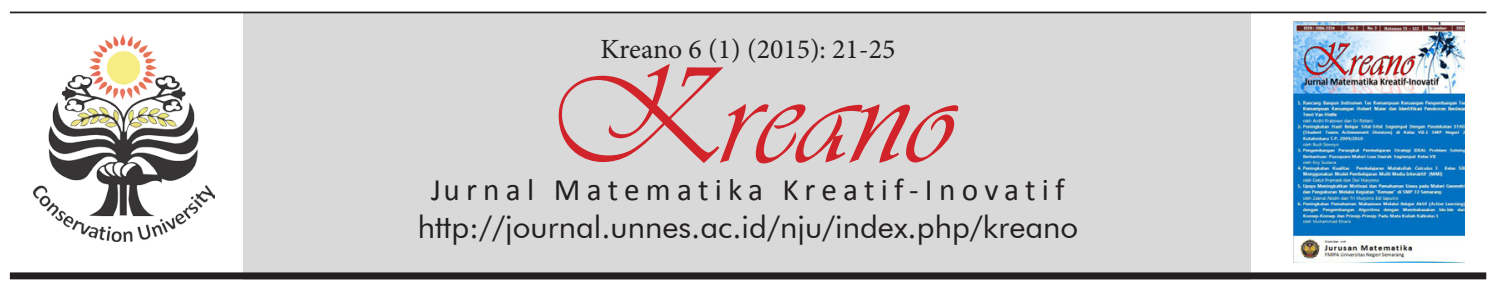

\title{
Profil Antisipasi Siswa SMA dalam Memecahkan Masalah Integral
}

\author{
Erfan Yudianto' \\ 'Program Studi Pendidikan Matematika FKIP UNEJ \\ Email: erfanyudi@unej.ac.id
}

DOI: http://dx.doi.org/10.15294/kreano.v6i1.4472

Received : August 2015; Accepted: September 2015; Published: September 2015

\begin{abstract}
Abstrak
Penelitian ini dilatarbelakangi oleh sulitnya siswa dalam menyelesaikan masalah integral khusunya luas daerah. Banyak siswa hanya menyelesaikan masalah integral hanya berdasarkan rumus yang sudah disediakan. Siswa jarang mengaitkan konsep-konsep yang saling terkait, dalam hal ini konsep integral subpokokbahasan luas daerah.Tujuan penelitian ini untuk mendeskripsikan Profil antisipasi siswa SMA dalam memecahkan masalah integral. Hasil penelitian ini dapat dimanfaatkan oleh guru untuk membantu siswa mengaitkan konsep-konsep yang belum terkait. Penelitian ini menggunakan metode tes dan wawancara. Tes berupa tes kemampuan matematika yang diberikan kepada siswa, sehingga diperoleh siswa berkemampuan tinggi dan wawancara diberikan kepada siswa yang bersangkutan untuk menggali dan melihat jaringan konsep yang dimiliki siswa dalam menyelesaikan masalah integral. Subjek dalam penelitian ini termasuk dalam antisipasi terinternasilsasi dikarenakan siswa secara spontan menerapkan rumus integral tanpa menganalisis soal yang diberikan.
\end{abstract}

\begin{abstract}
This research is motivated by the difficulty of students in solving integral problems especially the area. Many students just completed the integral problems just based on a formula that has been provided. Students rarely associate the concepts are interrelated, in this case the integral concept of the area. The purpose of this study was to describe the profile anticipation of high school students in problem solving integrals. The results could be used by teachers to help students link the concepts are not related. This study uses tests and interviews. The tests such as math skills test given to students, in order to obtain a high ability students and interviews given to the student to explore and see the network concept of the students in problem solving integrals. Subjects in this study are included in anticipation terinternasilsasi because students spontaneously apply the integral formula without analyzing the questions that were given
\end{abstract}

Keywords:

\section{PENDAHULUAN}

Dalam menyelesaikan masalah matematika siswa pasti memanfaatkan pengetahuannya dalam berpikir, sebelum melakukan tindakan mental (berpikir), melalui proses pemahaman di dalam otaknya. Jika siswa tidak mampu memahami maksud dari soal yang dibaca maka siswa akan mengalami konflik kognitif dalam memahami masalah tersebut. Hal ini sejalan dengan pendapat Lim (2006: 106) mengatakan bahwa siswa akan mengantisipasi setiap tindakan mental yang dia lakukan. Jika antisipasi yang dilakukan siswa salah, maka siswa akan mengalami konflik kognitif. Lebih lanjut, Harel (2006) mengatakan bahwa konflik kog- nitif dapat membantu siswa meningkatkan cara bepikir dan cara memahami suatu masalah.

Salah satu pokok bahasan dalam matematika adalah integral. Materi integral dirasa sulit bagi siswa dikarenakan materi integral merupakan materi yang komplek. Hal ini dapat dilihat dari hasil tryout Ujian Nasional (UN) tahun pelajaran 2013/2014 di kabupaten Jember hanya 33,33\% siswa menjawab benar pada materi integral yang diujikan (berdasarkan Standar Kelulusan tahun 2013). Hal ini didukung oleh pendapat Misdalina, Zulkardi, dan Purwoko (2009: 61) bahwa siswa hanya diberi materi integral berupa rumus-rumus 
dan contoh soal kemudian siswa dilatih secara drill agar terampil menyelesaikan soal. Hal ini berarti jika siswa tidak dilatih secara drill maka siswa tidak mampu mengerjakan soal itu, sehingga dapat dikatakan pemahaman siswa rendah pada materi integral.

Dalam penelitian ini, untuk mengkaji profil antisipasi siswa didasarkan pada proses asimilasi dan akomodasi dari Piaget. Piaget mengatakan bahwa struktur kognitif merupakan skemata, yaitu sekumpulan dari skemaskema (struktur-struktur). Jika skemata bekerja (aktif) dan saling terkait, maka seseorang dapat mengingat, memahami dan memberikan respon terhadap stimulus. Skemata berkembang sebagai hasil dari interaksi individu dengan lingkungannya. Skemata membentuk suatu pola penalaran tertentu dengan pikiran. Semakin baik kualitas skemata, maka akan semakin baik juga pola penalaran seseorang. Selanjutnya Piaget (dalam Solso: 1995) mengatakan bahwa fungsi kognitif merupakan salah satu unsur dalam perkembangan kognitif seseorang. Fungsi kognitif menunjukkan sifat dari intelektual, yaitu proses asimilasi dan akomodasi yang tetap dan terus menerus sepanjang perkembangan kognitif. Perkembangan struktur kognitif hanya bisa berjalan jika seseorang mengasimilasi dan mengakomodasi rangsangan dari lingkungannya. Asimilasi dan akomodasi yang dilakukan seseorang (siswa) tidak dapat terlepas dari ketiga hubungan yang digagas oleh Harel (in press $a$ ) seperti terlihat pada gambar 1.

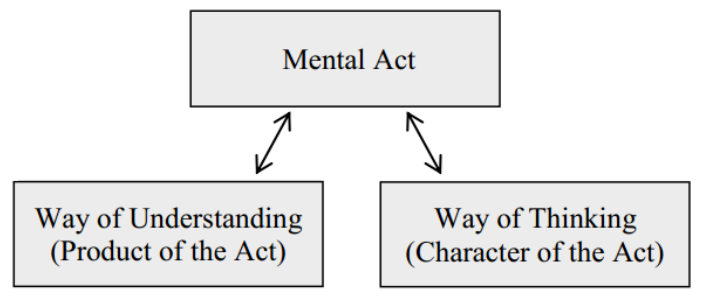

Gambar 1. Hubungan Cara Memahami-Tindakan Mental-Cara Berpikir dari Harel

Dalam memahami masalah, siswa membutuhkan tindakan mental dan kemudian akan dilanjutkan pada kegiatan berpikir. Dalam memahami masalah, siswa akan memperoleh hasil tertentu (product) kemudian dilanjutkan pada kegiatan berpikir yang meru- pakan karakteristik dari kegiatan memahami di atas. Antisipasi siswa dalam memahami masalah khususnya masalah matematika sangat dibutuhkan untuk mendapatkan suatu solusi khusus (eksak) dalam matematika yang bernilai benar. Jika siswa salah dalam mengantisipasi masalah yang diberikan maka siswa juga akan salah dalam memahami soal tersebut, dan pada akhirnya akan terjadi misconcepsi. Hal ini juga terkait dengan jaringan konseptual yang dimiliki siswa tidak saling terkait antara satu dengan yang lainnya.

Berdasarkan uraian di atas dapat dikatakan bahwa antisipasi siswa dalam menyelesaikan masalah memiliki peran penting dalam menentukan tindakan yang akan diambil dalam menyelesaikan masalah. Oleh karena itu dirasa perlu diadakan penelitian mengenai profil antisipasi siswa dalam menyelesaikan suatu masalah.

Berdasarkan latar belakang yang telah diuraikan, maka pertanyaan penelitian yang diajukan adalah "bagaimanakan profil antisipasi siswa SMA dalam memecahkan masalah integral"?

\section{METODE}

Tujuan penelitian ini adalah memperoleh informasi profil antisipasi siswa SMA dalam memecahkan masalah integral. Dalam melakukan pemeriksaan itu, peneliti bertindak sebagai instrumen utama artinya keberadaan peneliti tidak dapat digantikan oleh orang lain ataupun sesuatu yang lain. Peneliti juga tidak melakukan manipulasi terhadap suatu variabel yang lain. Peneliti lebih mengutamakan hal-hal yang dilakukan oleh siswa pada saat kegiatan pengambilan data. Dengan demikian, penelitian ini menggunakan pendekatan kualitatif (Moleong, 2002: 4-8). Jika dilihat dari tujuan penelitian maka penelitian ini merupakan penelitian deskriptif sedangkan jika dilihat dari tujuan spesifiknya yaitu mengeksplorasi apa yang dipikirkan dan dilakukan oleh siswa, maka penelitian ini tergolong penelitian eksploratif. Dengan demikian jenis penelitiannya adalah deskriptif-eksploratif.

Sedangkan subjek yang diambil dalam penelitian ini adalah siswa SMA kelas XII berkemampuan tinggi. Tes penentuan subjek tersebut terdiri dari 5 soal pilihan ganda dan 
5 soal esai. Kriteria skor yang digunakan adalah dari akumulasi penskoran dari kedua tes tersebut (pilihan ganda dan esai) yaitu siswa berkemampuan tinggi jika memperoleh skor $\geq \mathbf{6}, \overline{6}$, siswa berkemampuan sedang jika $3,3 \leq$ skor $\leq \mathbf{6}, 6$ dan siswa berkemampuan rendah jika skor $\leq \mathbf{3}, \mathbf{3}$, dimana penentuan kriteria skor menggunakan pembagian sama rata dari tiga subjek yang diinginkan yaitu antara skor o sampai 100.

\section{HASIL DAN PEMBAHASAN}

Hasil penelitian kepada siswa kelas XII dan uji coba dilakukan pada tanggal 2 Februari 2015. Siswa berkemampuan tinggi terlihat semangat dalam menyelesaikan masalah yang diberikan,

setelah diberikan permasalah matematika berupa luas daerah. Siswa merasa dan menganggap masalah yang diberikan itu mudah karena semua informasi yang diberikan pada soal sudah lengkap termasuk batas bawah dan batas atasnya (terlihat pada interval).

\section{Permasalahan}

Tentukan luas daerah yang dibatasi kurva $y=2 x^{2}-8$, dan sumbu $X$ pada interval $0 \leq x \leq 3$ ? (sumber: Ebtanas IPA tahun 2000)

Hasil pekerjaan siswa seperti terlihat pada Gambar 2.

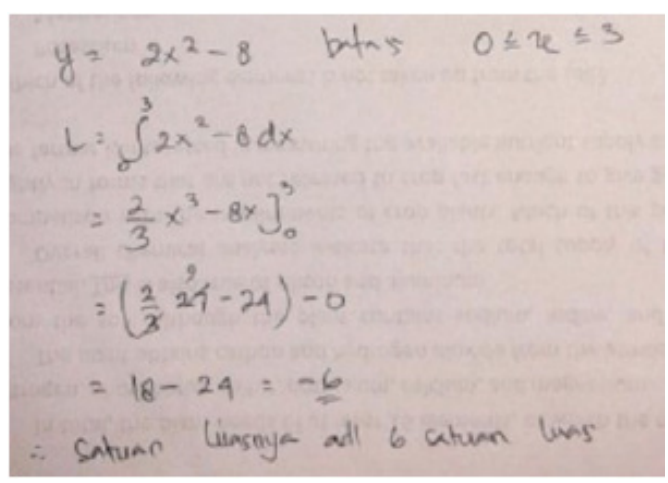

Gambar 2. Hasil Pekerjaan Siswa Masalah Luas Daerah

Gambar 2 merupakan salah satu hasil pekerjaan siswa dalam menyelesaikan masalah luas daerah. Dapat diidentifikasi bahwa siswa menyelesaikan masalah luas daerah langsung memutuskan untuk mengerjakan soal yang diberikan karena siswa merasa mampu dalam menyelesaikannya. Secara langsung siswa menentukan batas bawah yaitu o dan batas atas yaitu 3 sesuai dengan informasi yang diberikan soal. Kemudian siswa langsung menyelesaikan soal integral itu dan menghasilkan nilai akhir -6 . Dari hasil wawancara, siswa menjelaskan bahwa yang ditulis adalah 6 saja, siswa beralasan karena tidak ada luas daerah yang bernilai negatif. Alasan siswa sangat tepat dalam memahami hasil akhir luas daerah yaitu tidak ada luas daerah yang bernilai negatif.

Antisipasi yang dilakukan siswa pada Gambar 2 termasuk antisipasi interiorized (antisipasi terinternalisasi) yaitu antisipasi yang diinternalisasi dalam pikiran siswa. Seseorang dalam situasi ini secara spontan melakukan suatu proses tindakan (cara menyelesaikan masalah) tanpa menganalisis situasi yang ada. Jika melihat lagi hasil pekerjaan siswa pada gambar 2, siswa langsung menerapkan rumus integral yang sudah diketahui tanpa memahami kembali maksud dari soal yang diberikan. Hal ini berarti jaringan konsep yang siswa miliki dapat dikatakan kurang atau sebenarnya siswa memiliki konsep-konsep tersebut tetapi siswa kesulitan dalam memanggil kembali (recall) konsep yang ada di otaknya, atau dengan kata lain siswa kesulitan dalam mengaitkan konsep-konsep yang ada di otaknya. Hal ini sesuai dengan hasil penelitian Cobb (1985: 123) bahwa jaringan konseptual merupakan unsur yang paling dasar dan paling menentukan antisipasi. Jaringan konsep untuk masalah integral (penerapan rumus) sebenarnya sudah terbentuk tetapi jaringan yang terbentuk di pikiran siswa belum komplek (tidak tepat) dalam penerapannya. Hal ini terlihat dalam kutipan wawancaa berikut.

P : Apakah Mz sudah pernah melihat soal seperti ini? (menunjuk soal yang diberikan)

$S$ : Sudah pak

P : Jika Mz dapat soal seperti itu, lalu apa yang Mz lakukan?

$S$ : Saya langsung kerjakan pak

P : Tanpa melakukan hal lainnya?

S : lya pak ... soal itu sudah jelas batas ba- 
wah dan batas atasnya, jadi tinggal dimasukkan ke rumus.

Kalimat terakhir dari kutipan wawancara di atas memberikan gambaran bahwa siswa "tidak mampu" mengaitkan masalah integral dengan beberapa materi yang terkait langsung dengan soal yang diberikan di atas. Materi yang dimaksud adalah masalah menggambar grafik. Padahal konsep dasar yang harus dimiliki siswa saat mengerjakan soal integral sub pokok bahasan luas daerah adalah dengan mensketsa grafik fungsi terlebih dahulu kemudian menentukan batas-batas baru untuk menentukan daerah-daerah yang terbentuk, kemudian menerapkan rumus yang sesuai.

Sebenarnya di dalam kepala siswa pada saat memulai belajar tidak kosong, tetapi sudah terisi dengan pengetahuan awal yang berhubungan dengan pengetahuan yang akan dipelajari, dan pengetahuan tersebut diperoleh dari lingkungan atau pelajaran pada jenjang pendidikan sebelumnya Johar (1996: 1). Ruseffendi (1988: 152) mengatakan bahwa pengetahuan yang dimaksudkan tidak terlepas dari topik matematika yang sedang dipelajari, sedang suatu topik dalam matematika bukanlah berdiri sendiri melainkan adanya suatu keterkaitan dengan topik lain. Sedangkan Menurut Yudianto (2013) mengatakan bahwa pengetahuan awal siswa dapat berupa pengetahuan yang sudah cocok dengan pengetahuan yang akan dipelajari (konsepsi awal atau prakonsepsi) atau berbeda sama sekali (misconcepsi).

Berdasarkan pendapat-pendapat di atas berarti jaringan konseptual siswa bukan hanya dilihat 'kaya' atau 'miskin' pengetahuan konsep yang dimiliki siswa, tetapi bagaimana siswa mampu mengaitkan skema-skema yang dimiliki menjadi satu kesatuan yang saling terkait dan dimanfaatkan untuk memperoleh satu simpulan yang tepat, inilah hakekat dari antisipasi.

Dikatakan siswa termasuk pada golongan antisipasi terinternalisasi karena siswa pada penelitian ini tetap meyakini apa yang dia kerjakan meskipun peneliti memberikan kesempatan kepada siswa untuk mencoba memeriksa kembali hasil pekerjaannya. Hal ini terlihat dalam kutipan wawancara berikut.

$\mathrm{P}$ : Apakah itu sudah benar apa yang mz kerjakan?

$S$ : Sudah pak, saya yakin itu

$\mathrm{P}$ : Coba $\mathrm{mz}$ jelaskan kembali apa yang $\mathrm{mz}$ kerjakan!

S : Itu soalnya kan sudah jelas bapak, dengan batas bawah o dan batas atas 3

$P$ : Terus

S : Ya gampang pak, tinggal masukkan saja hehehehe ..... dan hasilnya - 6

Berdasarkan kutipan wawancara di atas, dapat kita pahami bahwa siswa benar-benar sudah menginternalisasi di dalam pikirannya bahwa penggunaan rumus dan pengerjaannya sudah benar. Siswa tanpa menganalisis terlebih dahulu dalam mengerjaan soal, bahkan saat peneliti memberi kesempatan siswa untuk mengecek kembali hasil pekerjaannya, siswa tetap yakin terhadap apa yang dia kerjakan.

\section{SIMPULAN}

Berdasarkan hasil penelitian ini diperoleh profil siswa berkemampuan matematika tinggi dalam memecahkan masalah integral siswa termasuk pada golongan antisipasi terinternalisasi dimana siswa secara spontan menerapkan rumus integral tanpa menganalisis soal yang diberikan peneliti. Hal ini berarti jaringan konseptual siswa belum dapat dikatakan komplek karena tidak dapat mengaitkan antara skema-skema yang satu dengan yang lainnya yang telah dimiliki siswa.

\section{DAFTAR PUSTAKA}

Cobb, P. (1985). Two Children's Anticipation, beliefs, and Motivations. Educational Studies in Mathematics, 16(2), 111-126.

Harel, G. (2007). The DNR system as a conceptual framework for curriculum development and instruction. Foundations for the future in mathematics education, 263-280.

Johar, R. (1996). Model Kontruktivis untuk Membangkitkan Perubahan Konseptual Siswa dalam Matematika. Makalah. Pps IKIP Surabaya.

Lim, K. (2006). Characterizing students' thinking: Algebraic inequalities and equations. In S. Alatorre, J. L. Cortina, M. Sáiz \& A. Méndez (Eds.), Proc. 
28th Annual Meeting of the North American Chapter of the Int. Group for the Psychology of Mathematics Education, (2, 102-109). Mérida, México: PME-NA.

Moleong, L. J. (2011). Metodologi Penelitian Kualitatif. Bandung: PT Remaja Rosdakarya.

Misdalina, M., Zulkardi, Z., \& Purwoko, P. (2009). Pengembangan Materi Integral untuk Sekolah Menengah Atas (SMA) Menggunakan Pendekatan Pendidikan Matematika Realistik Indonesia (PMRI) di Palembang. Jurnal Pendidikan
Matematika, 3(1), 61-74.

Russeffendi, E.T. (1988). Pengantar Kepada Mambantu Guru Mengembangkan Kompetensinya dalam Pengajaran Matematika untuk Meningkatkan CBSA. Tarsito Bandung.

Solso, R, L. (1995). Cognitive Psychology (Fourth Edition). Boston: Allyn and Bacon.

Yudianto, E. (2013). Profil Pengetahuan Konseptual dan Pengetauan Prosedural Siswa dalam Mengidentifikasi Masalah Pecahan. Jurnal AdMathEdu, $3(1), 27-36$. 